South Dakota State University

Open PRAIRIE: Open Public Research Access Institutional Repository and Information Exchange

Agronomy, Horticulture and Plant Science Faculty Department of Agronomy, Horticulture, and Plant

Publications

Science

2006

Spatial Distribution, Temporal Stability, and Yield Loss Estimates for Annual Grasses and Common Ragweed (Ambrosia artimisiifolia) in a Corn/ Soybean Production Field Over Nine Years

Sharon A. Clay

Bruce Kreutner

David E. Clay

Cheryl Reese

Jonathan Kleinjan

See next page for additional authors

Follow this and additional works at: https://openprairie.sdstate.edu/plant_faculty_pubs

Part of the Weed Science Commons 
Authors

Sharon A. Clay, Bruce Kreutner, David E. Clay, Cheryl Reese, Jonathan Kleinjan, and Frank Forcella 


\section{Spatial distribution, temporal stability, and yield loss estimates for annual grasses and common ragweed (Ambrosia artimisiifolia) in a corn/soybean production field over nine years}

Sharon A. Clay

Corresponding author. Department of Plant Science, South Dakota State University, Brookings, SD 57007; Sharon.clay@sdstate.edu

Bruce Kreutner

David E. Clay

Cheryl Reese

Jonathan Kleinjan

Department of Plant Science, South Dakota State University, Brookings, SD 57007

Frank Forcella

USDA-ARS, North Central Soil Conservation Research Laboratory, Morris, MN 56267

\begin{abstract}
Weeds generally occur in patches in production fields. Are these patches spatially and temporally stable? Do management recommendations change on the basis of these data? The population density and location of annual grass weeds and common ragweed were examined in a 65-ha corn/soybean production field from 1995 to 2004. Yearly treatment recommendations were developed from field means, medians, and kriging grid cell densities, using the hyperbolic yield loss (YL) equation and published incremental $\mathrm{YL}$ values $(I)$, maximum $\mathrm{YL}$ values $(A)$, and $\mathrm{YL}$ limits of 5 , 10 , or $15 \%$. Mean plant densities ranged from 12 to 131 annual grasses $\mathrm{m}^{-2}$ and $<1$ to 37 common ragweed $\mathrm{m}^{-2}$. Median weed densities ranged from 0 to 40 annual grasses $\mathrm{m}^{-2}$ and were 0 for common ragweed. The grass $I$ values used to estimate corn YL were 0.1 and $2 \%$ and treatment was recommended in only $1 \mathrm{yr}$ when the high $I$ value and either the mean or median density was used. The grass $I$ values used for soybean were 0.7 and $10 \%$ and estimated YL was over $10 \%$ all years, regardless of $I$ value. The common ragweed $I$ values were 4.5 and $6 \%$ for corn and 5.1 and $15.6 \%$ for soybean. On the basis of mean densities, fieldwide treatment would have been recommended in 6 of $9 \mathrm{yr}$ but in no years when the median density was used. Recommendations on the basis of grid cell weed density and kriging ranged from $>80 \%$ of the field treated for grass weeds in 3 of $4 \mathrm{yr}$ in soybean to $<20 \%$ of the field treated for common ragweed in 2002 and 2004 (corn). Grass patches were more stable in time, space, and density than common ragweed patches. Population densities and spatial distribution generally were variable enough so that site-specific information within this field would improve weed management decisions.
\end{abstract}

Nomenclature: Common ragweed, Ambrosia artimisiifolia L. AMBEL; corn, Zea mays L. ZEAMA; soybean, Glycine max L. Merr. GLYMX.

Key words: Economic threshold, geostatistics, incremental yield loss, kriging, precision agriculture, site-specific weed management.
The patchiness of weeds in fields has been documented in the literature with weed maps of various size fields being generated by an assortment of models to show the uneven distribution of a variety of species (Cardina et al. 1995; Clay et al. 1999; Colbach et al. 2000b; Gaston et al. 2001; Marshall 1988). If weed location or density, or both, were similar each year this would simplify weed mapping (Colbach et al. 2000a) and improve weed management strategies. Information about temporal and spatial patch stability within a field is less common and often reported on a short-term (1 to $4 \mathrm{yr}$ ) rather than a long-term basis. In short-term studies, patches of some weed species [including common sunflower (Heliathus annuus L.), velvetleaf (Abutilon theophrasti Medik.), and hemp dogbane (Apocynum cannabinum L.)] were both temporally and spatially stable with moderate fluctuations in density and patch margin locations (Dieleman and Mortensen 1999; Gerhards et al. 1997; Johnson et al. 1996), whereas patches of other species [e.g., foxtail (Setaria spp.)] have been reported to be unstable (Johnson et al. 1995).

Weed patch stability and distribution have been described for a few long-term studies. For example, Chancellor (1985) mapped weeds in arable fields over a 20 -yr period, Wilson and Brain (1991) reported on blackgrass (Alopecurus myosuroides Huds.) distribution on the whole-farm basis over 10 yr, and Colbach et al. (2000b) examined the stability of several weed species in a field over 5 yr. These longer-term studies have shown spatial correlations of weed species among years (Wilson and Brain 1991), or at least species location predictability from one sampling year to the next (Colbach et al. 2000b). These types of data, although imperfect, still are useful in developing sampling and management strategies.

Broadcast herbicide applications for weed control within a field are still a normal field practice. Site-specific management is only practical when the weed density and species vary enough over a field to warrant location-specific treatment. In addition, application guides should estimate economic benefits of the treatment at a location to determine if benefits are high enough to justify treatment. Conservative producers might argue that any loss due to weeds is unacceptable, although single-year yield loss (YL) of 5 or $10 \%$ often is needed to pay for the treatment cost (on the basis of expected crop price, treatment cost, and yield). Lindquist 


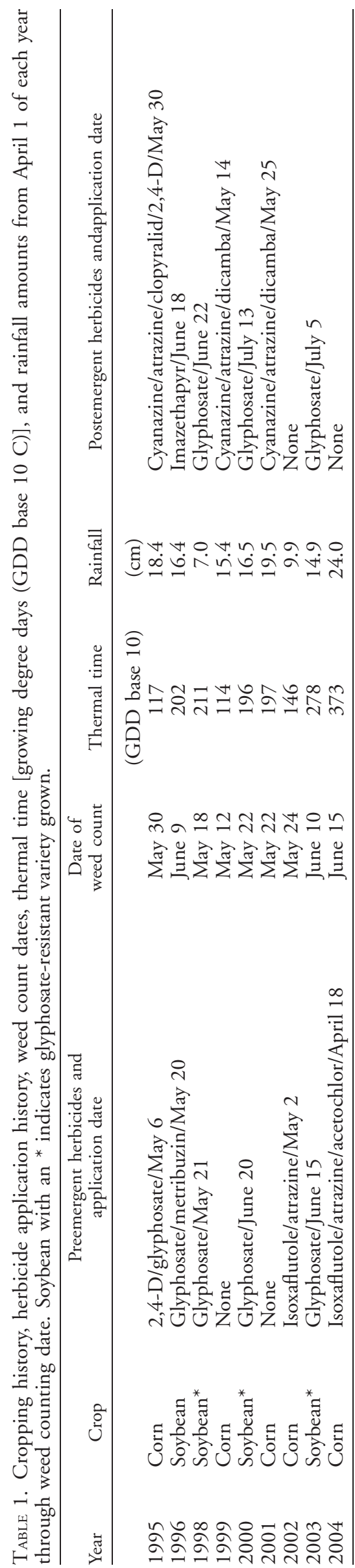

et al. (1999) estimated foxtail densities to range from 3 to 94 plants $\mathrm{m}^{-1}$ depending on year and location in the northcentral region of the United States to meet an economic threshold for corn on the basis of a treatment cost of $\$ 49.40$ $\mathrm{ha}^{-1}$, return of about $\$ 0.10 \mathrm{~kg}^{-1}, 90 \%$ removal of the foxtail by the treatment, and a corn yield of $10,115 \mathrm{~kg} \mathrm{ha}^{-1}$.

Jurado-Exposito et al. (2003) used a multispecies infestation severity index for sunflower that estimated YL by field location and developed site-specific treatment maps for areas exceeding threshold levels. A severity index of 2, based on weed species and density, that had densities as low as 1.2 weeds $\mathrm{m}^{-2}$ (Castro-Tendero and Garcia-Torres 1995) was used to identify treatment areas (Jurado-Exposito et al. 2003).

An alternative method would be to estimate YL using YL functions by crop and weed species/density at specific field locations. Yield losses in many crops due to different weeds have been calculated (Banken 2000; Bensch et al. 2003; Chikoye and Swanton 1995; Conley et al. 2003; Cowbrough et al. 2003; Lindquist et al. 1999; Moechnig et al. 2003; OMAF 2003; Weaver 2001) using a hyberbolic YL model (Cousens 1985). The hyberbolic model that Cousens (1985) proposed originally was based only on weed density and estimated two parameters: (1) a maximum YL $(A)$ when weed densities approach infinity (e.g., no more than $100 \%$ YL can occur) and (2) an incremental YL value $(I)$ that estimates the percent YL per weed per unit area as the weed density approaches zero. Modifications to the original model have included data on weed leaf area and relative time of weed emergence to the crop (Bensch et al. 2003; Chikoye and Swanton 1995; Moechnig et al. 2003). The $I$ and $A$ values, regardless of the method chosen, have been reported to be highly variable from year to year even with one weed species in a single crop at the same (Banken 2000; Bensch et al. 2003; Moechnig et al. 2003; Weaver 2001) or different (Lindquist et al. 1999) locations. The variations in these values can be attributed to many causes including crop cultivar, fertility (Banken 2000; Cathcart and Swanton 2003; Clay et al. 2006; Evans et al. 2003; Tollenaar et al. 1994), row spacing (Anderson 2000; Forcella et al. 1992), climate (Lindquist et al. 1999), time of weed removal or weed emergence (Bensch et al. 2003; Evans et al. 2003), and soil factors (Gaston et al. 2001). Since these estimated values are unstable, using a range of values for a weed species within a crop and year would help determine treatment areas for the "best" and "worst" cases of crop loss. The objectives of this research were to (1) examine the spatial and temporal stability of annual grass (combinations of green foxtail [Setaria viridis (L.) Beauv.], yellow foxtail [Setaria pumila (Poir.) Roem. \& Schult. syn. Setaria gluca (L.) Beauv.], and barnyardgrass [Echinochloa crus-galli L.]) and common ragweed infestations in a corn/soybean production field, (2) use several $I$ and $A$ values to estimate YL on the basis of mean, median, and site-specific weed densities, and (3) produce treatment maps to examine the similarity and differences of the management maps by weed species, crop, and year.

\section{Materials and Methods}

The dryland 65-ha production field used for this study is located in east-central South Dakota $\left(44.17^{\circ} \mathrm{N},-96.63^{\circ} \mathrm{W}\right)$, and details of the study site have been published by Clay et 


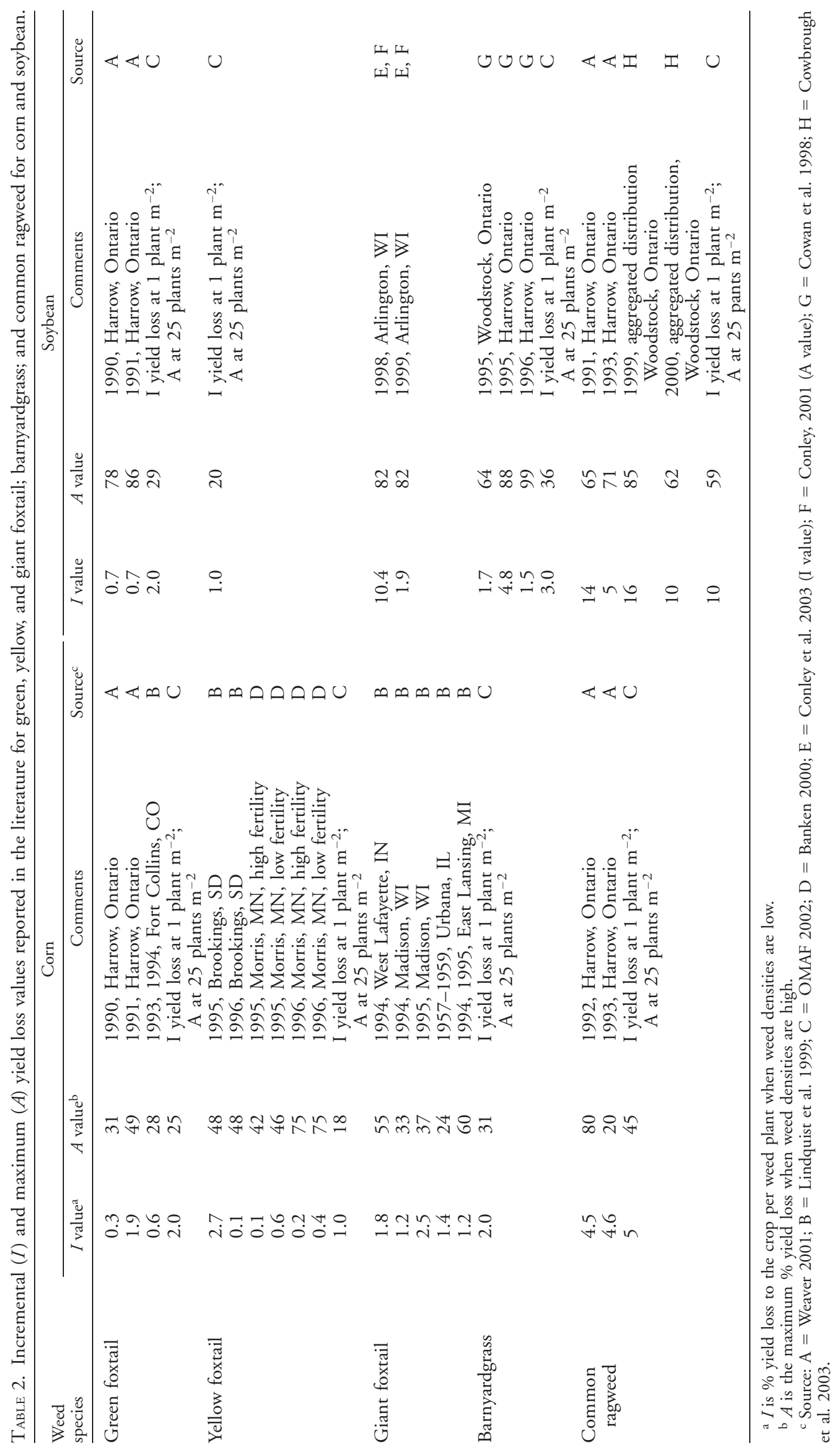


TABLE 3. Mean, standard deviation of the mean, median plant counts, skewness, and kurtosis for annual grasses (green and yellow foxtail and barnyardgrass) and common ragweed in a corn/soybean rotation production field in Moody County, SD, from 1995 to 2004. Weed counts were taken in the spring of each year.

\begin{tabular}{|c|c|c|c|c|c|c|c|c|c|}
\hline \multirow[b]{2}{*}{ Weed type } & \multicolumn{9}{|c|}{ Year } \\
\hline & $\begin{array}{l}1995^{a} \\
\text { Corn }\end{array}$ & $\begin{array}{c}1996^{a} \\
\text { Soybean }\end{array}$ & $\begin{array}{c}1998 \\
\text { Soybean }\end{array}$ & $\begin{array}{l}1999 \\
\text { Corn }\end{array}$ & $\begin{array}{c}2000 \\
\text { Soybean }\end{array}$ & $\begin{array}{l}2001 \\
\text { Corn }\end{array}$ & $\begin{array}{l}2002^{\mathrm{a}} \\
\text { Corn }\end{array}$ & $\begin{array}{c}2003 \\
\text { Soybean }\end{array}$ & $\begin{array}{l}2004^{\mathrm{a}} \\
\text { Corn }\end{array}$ \\
\hline \multicolumn{10}{|l|}{ Annual grasses } \\
\hline Mean (plants $\mathrm{m}^{-2}$ ) & 14 & 76 & 100 & 29 & 69 & 54 & 47 & 131 & 12 \\
\hline Mean std dev & 54 & 189 & 148 & 69 & 48 & 112 & 91 & 220 & 38 \\
\hline Median (plants $\mathrm{m}^{-2}$ ) & 0 & 2.5 & 15 & 2.5 & 15 & 15 & 0 & 40 & 0 \\
\hline Skewness & 7.5 & 4.1 & 1.5 & 3.9 & 2.2 & 2.3 & 2.8 & 2.8 & 6.9 \\
\hline Kurtosis & 75.9 & 0 & 4.1 & 21.7 & 7.3 & 8.6 & 11.9 & 12.7 & 67.4 \\
\hline \multicolumn{10}{|l|}{ Common ragweed } \\
\hline Mean (plants $\mathrm{m}^{-2}$ ) & 37 & 10 & 12 & 10 & 3 & 8 & $<1$ & 1 & 2 \\
\hline Mean std dev & 105 & 45 & 38 & 280 & 10 & 19 & 2 & 5 & 10 \\
\hline Median (plants $\mathrm{m}^{-2}$ ) & 0 & 0 & 0 & 0 & 0 & 0 & 0 & 0 & 0 \\
\hline Skewness & 4.3 & 11.8 & 4.8 & 6.6 & 4.8 & 4.1 & 8.7 & 7.2 & 12.5 \\
\hline Kurtosis & 6.8 & 190 & 28.8 & 64.5 & 30.2 & 24.9 & 7.8 & 75.5 & 203 \\
\hline
\end{tabular}

a Sample counts were taken after preplant or preemergence herbicide application had occurred.

al. (1999). The grower selected crop rotations, tillage, and herbicide treatments, and broadcast-sprayed the entire field each year with his choice of herbicides based on his schedule (Table 1). The field was in no-till from 1992 to 2000. Strip tillage was used in 2001 through 2004 where $10-\mathrm{cm}$ strips on $76-\mathrm{cm}$ rows were tilled and planted. A corn/soybean rotation was used except when corn followed corn in 2001 and 2002. Conventional soybean varieties were planted before 1997 and glyphosate-resistant soybean varieties were planted in 1998, 2000, and 2003.

The field was sampled for emerged weeds each spring from 1995 through 2004 (except 1997) on about a 15 by $30 \mathrm{~m}$ grid. Weed counts were taken before postemergence herbicide application (Table 1). In 4 of the $9 \mathrm{yr}$, a pre- emergence herbicide treatment had been applied 11 to 58 $\mathrm{d}$ before counting but another flush of weeds had emerged before counting occurred. Weeds were identified and counted by species in a $0.1 \mathrm{~m}^{2}$ quadrat at each grid point and multiplied by 10 to estimate densities per square meter. Sampling points were staked and georeferenced using a differential global positioning system that had a spatial resolution of $2 \mathrm{~cm}$. Exact grid point positions varied among years. Therefore, a common 30 by $30 \mathrm{~m}$ grid was established across the field with the yearly density determined by averaging values from point data within the cell each year. The number of 15 by $30 \mathrm{~m}$ points within each common cell ranged from one to three and resulted in about 650 common data cells.

TABLE 4. The frequency distribution of plant counts per square meter of annual grasses (green and yellow foxtail and barnyardgrass) and common ragweed for sampling point data from 1995 to 2004 in a Moody County, SD, field. The 95\% confidence interval was calculated from the confidence interval for a probability using the formula shown in Equation 1. The maximum confidence interval for any observation was \pm 0.04 , indicating that values within a column or row separated by less than 0.04 are similar.

\begin{tabular}{|c|c|c|c|c|c|c|c|c|c|}
\hline \multirow[b]{2}{*}{ Weed type } & \multirow[b]{2}{*}{ Crop } & \multirow[b]{2}{*}{ Year } & \multicolumn{7}{|c|}{ Frequency of plant count (plants $\mathrm{m}^{-2}$ ) } \\
\hline & & & 0 & 1 to 10 & 11 to 20 & 21 to 30 & 31 to 40 & 41 to 50 & $51+$ \\
\hline \multirow{7}{*}{ Annual grass } & & & & - No. c & ells within & he increm & t/total cell & umber - & \\
\hline & Soybean & $1996^{a}$ & 0.49 & 0.15 & 0.03 & 0.04 & 0.03 & 0.02 & 0.23 \\
\hline & Soybean & 1998 & 0.31 & 0.16 & 0.07 & 0.03 & 0.03 & 0.01 & 0.38 \\
\hline & Corn & 1999 & 0.49 & 0.19 & 0.07 & 0.04 & 0.03 & 0.03 & 0.14 \\
\hline & Corn & $2002^{\mathrm{a}}$ & 0.51 & 0.08 & 0.05 & 0.06 & 0.03 & 0.01 & 0.25 \\
\hline & Soybean & 2003 & 0.24 & 0.14 & 0.05 & 0.04 & 0.04 & 0.04 & 0.44 \\
\hline & Corn & $2004^{a}$ & 0.66 & 0.15 & 0.06 & 0.03 & 0.02 & 0.01 & 0.05 \\
\hline \multirow[t]{4}{*}{ Common ragweed } & Corn & $1995^{\mathrm{a}}$ & 0.64 & 0.12 & 0.03 & 0.02 & 0.02 & 0.01 & 0.15 \\
\hline & Soybean & $1996^{a}$ & 0.79 & 0.07 & 0.04 & 0.02 & 0.01 & 0.01 & 0.05 \\
\hline & Soybean & 1998 & 0.75 & 0.06 & 0.06 & 0.02 & 0.01 & 0.01 & 0.08 \\
\hline & Soybean & $2004^{\mathrm{a}}$ & 0.89 & 0.07 & 0.01 & 0.01 & 0.00 & 0.00 & 0.01 \\
\hline
\end{tabular}

a Years when counts were taken after a preplant or preemergence herbicide treatment. 
TABle 5. Frequency of annual grass species and common ragweed to be found in the same grid cell from 0,1 to 2 y (low stability), 3 to 5 y (moderate stability), to 6+ y (high stability) in a Moody County, SD, field. The 95\% confidence interval was calculated from the confidence interval for a probability using the formula presented in Table 4 . The maximum confidence interval for any observation was \pm 0.03 , indicating that values separated by less than 0.03 are similar.

\begin{tabular}{lcccc}
\hline \multirow{2}{*}{ Weed type } & $\begin{array}{c}\text { Never found } \\
0 \text { yr }\end{array}$ & $\begin{array}{c}\text { Low stability } \\
1 \text { to } 2 \text { yr }\end{array}$ & $\begin{array}{c}\text { Moderate stability } \\
3 \text { to } 5 \text { yr }\end{array}$ & $\begin{array}{c}\text { High stability } \\
6 \text { to } 8 \text { yr }\end{array}$ \\
\cline { 2 - 5 } Grass & & Frequency of the weed to be in a cell & \\
Common ragweed & 0.06 & 0.23 & 0.40 & 0.30 \\
\hline
\end{tabular}

Mean, mean standard deviation, and median of weed densities, as well as skewness and kurtosis values of the data set were calculated for each species by year. Frequency of specific plant densities $(0,1$ to 10,11 to 20,21 to 30,31 to 40,41 to 50 , and more than 50 plants $\mathrm{m}^{-2}$ ) by grid cell were determined yearly by species to examine temporal density patterns. The frequency at which weed species occurred in the same grid cell across years was determined to assess their temporal stability. A 95\% confidence interval was calculated for frequency data using the formula:

$$
Y / n \pm \chi_{1-\alpha}\left(Y[n-Y] / n^{3}\right)^{1 / 2}
$$

where $Y=$ the number of times the event was counted; $n$
$=$ number of samples, and $\chi_{1-\alpha}$ is the quantile of a normally distributed random variable (Conover 1980).

$\mathrm{YL}$ estimates by weed type and crop were derived from the formula:

$$
\mathrm{YL}=I D /(1+[I D / A])
$$

where $I$ is a published incremental YL ( $\%$ per weed $\mathrm{m}^{-2}$ ) for the weed, $D$ is the estimated density of the weed, and $A$ is the maximum percentage of YL at high weed densities (Cousens 1985). Low and high I values, and low, high, and average $A$ values for crop loss per weed were chosen from a range of published $I$ and $A$ values (Table 2). The $I$ values for $\%$ YL per annual grass plant $\mathrm{m}^{-2}$ were 0.1 to $2 \%$ in
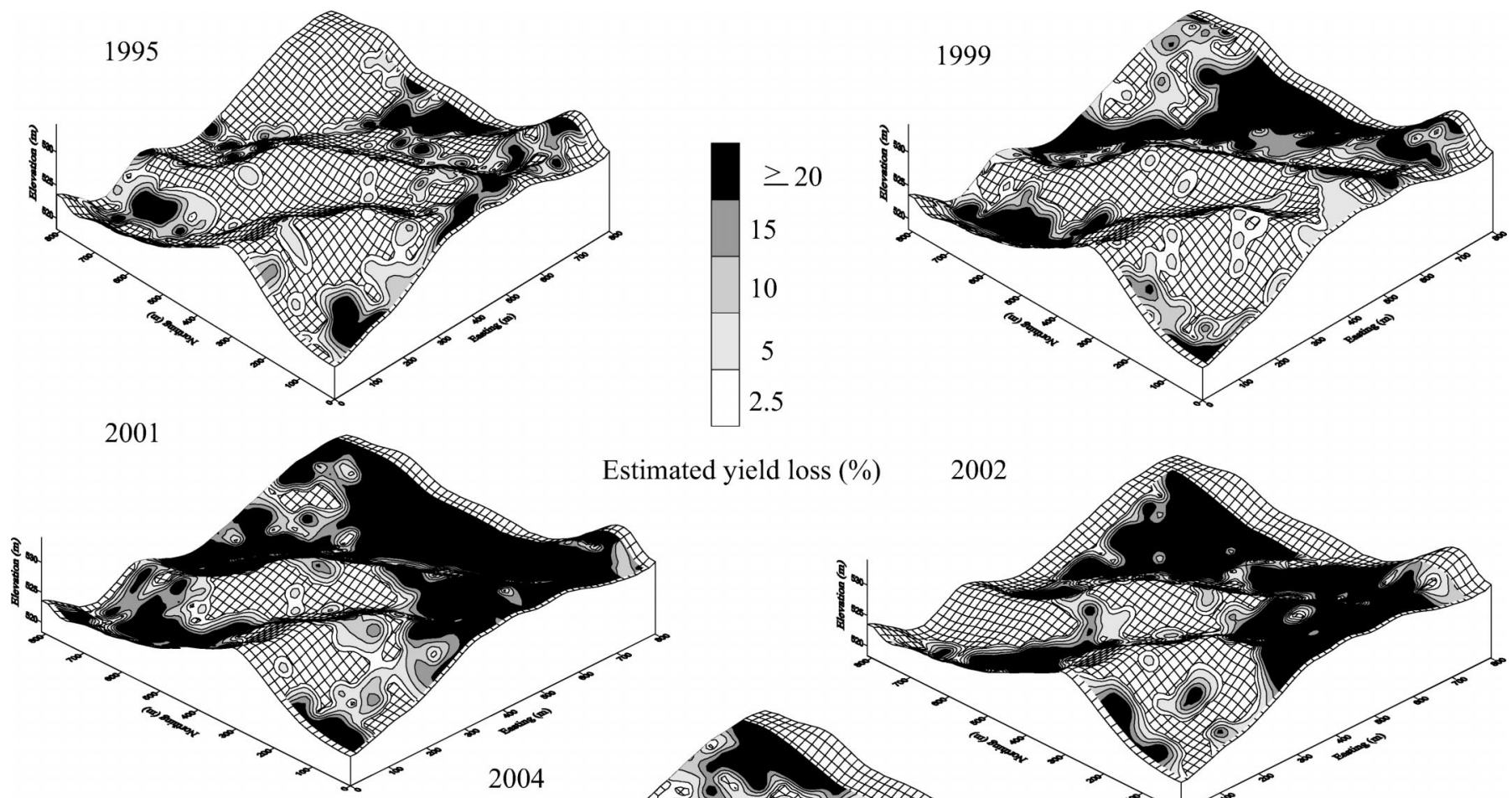

2002

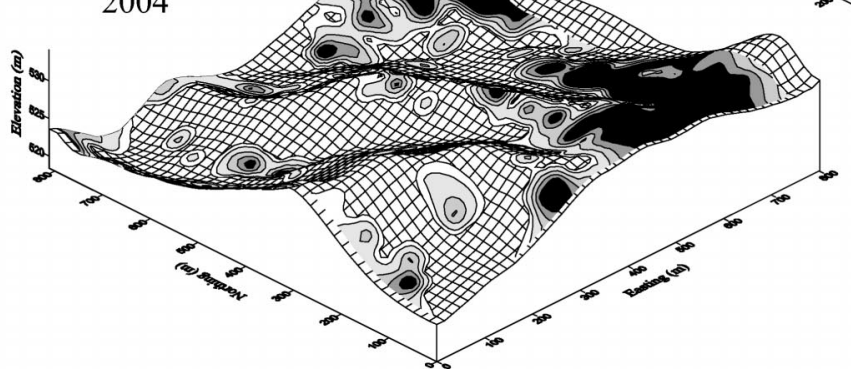

Figure 1. Estimated corn yield losses (YL) on the basis of kriging grass density per grid cell, an incremental YL value $(I)$ of $2 \%$ (Lindquist et al. 1999), and a maximum YL value $(A)$ of $43 \%$. 


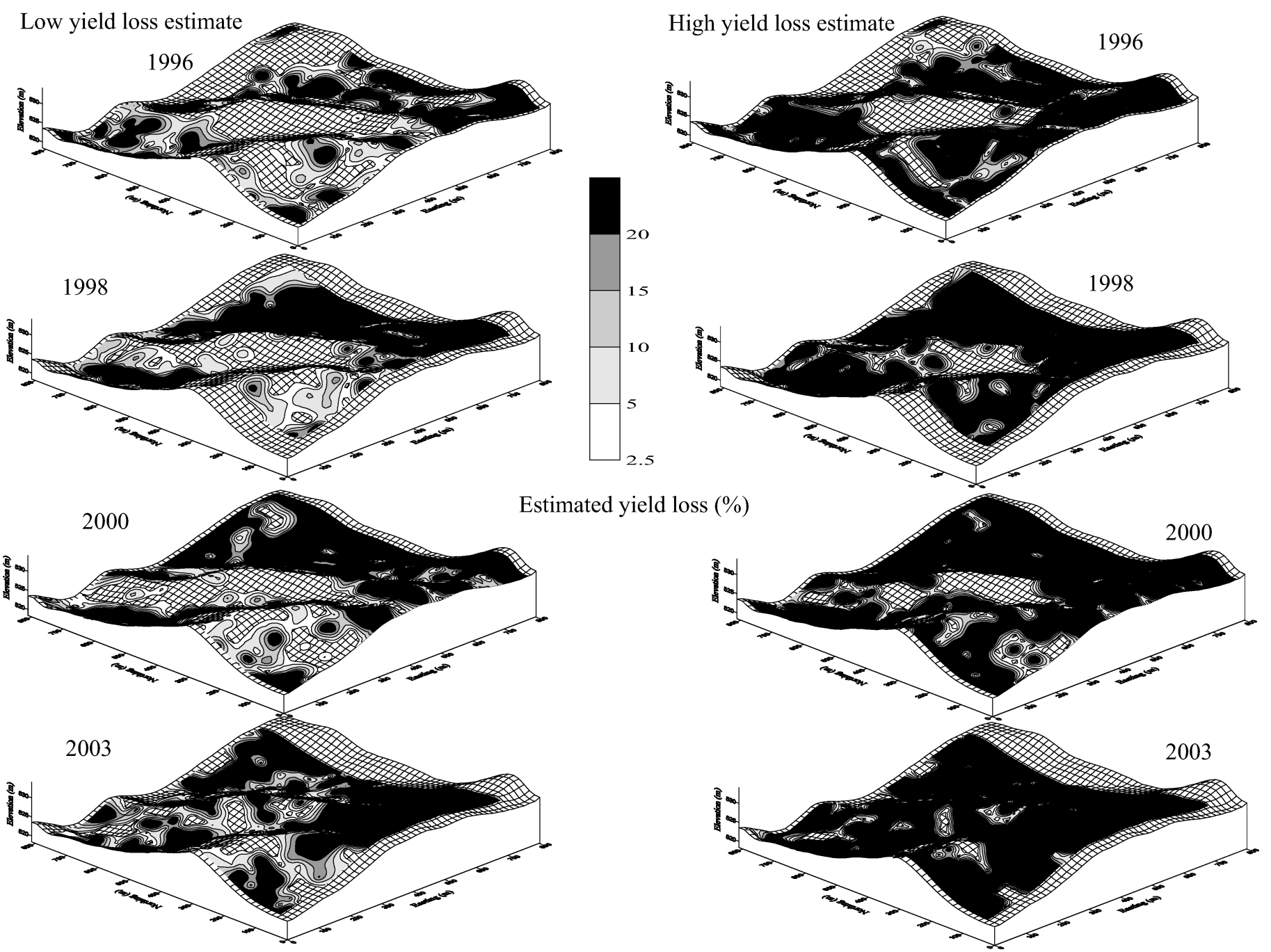

Figure 2. Estimated soybean yield losses (YL) on the basis of kriging grass density per grid cell, an incremental YL value $(I)$ of $0.7 \%$ (Weaver 2001$)$ for the low YL estimate and 10\% (Conley et al. 2003) for the high YL estimate, and a maximum YL value $(A)$ of $66 \%$.

corn (on the basis of yellow foxtail, Brookings, SD; Lindquist et al. 1999) and in soybean, $0.7 \%$ (on the basis of green foxtail, Harrow, Ontario, Canada; Weaver 2001) and $10 \%$ (on the basis of giant foxtail, Wisconsin; Conley et al. 2003). Chosen $I$ values for YL per common ragweed plant $\mathrm{m}^{-2}$ were 4.5 and $6 \%$ in corn (on the basis of data from Harrow, Ontario Canada; Weaver 2001) and in soybean, $5.1 \%$ (Weaver 2001) and $15.6 \%$ (on the basis of data of aggregated common ragweed distribution Woodstock, Ontario Canada; Cowbrough et al. 2003). The selected corn $A$ values for annual grass weeds were 25,43 , and $75 \%$ whereas soybean $A$ values were 20,66 , and $100 \%$. The corn $A$ values for common ragweed were 20,50 , and $80 \%$, and 60,68 , and $85 \%$ for losses in soybean. The weed densities that caused estimated YL to be 5, 10, or $15 \%$ were used for treatment recommendation.

The estimated YL per grid cell also were imported into the Surfer $8^{1}$ mapping system and YL in unsampled areas were estimated by kriging (Isaaks and Srivastava 1989) for each year. The areas and percentage of the field where treatment would be recommended on the basis of the above criteria were compared. Because estimated YL is a mathematical manipulation of weed density, to avoid redundancy only YL data are presented but spatial weed densities can be inferred from the YL results.

\section{Results and Discussion}

\section{Spatial and Temporal Stability of Annual Grass Species}

The cumulative thermal units (growing degree days [GDD], base $10 \mathrm{C}$ ) and rainfall measured from April 1 of each year to the day of weed counting differed considerably among years (Table 1). Cumulative GDD ranged from 114 in 1999 (April 1 through May 12) to 373 in 2004 (April 1 through June 15). A strong positive relation (adj $r^{2}=0.89$; $\mathrm{P}<0.0002$ ) was found between grass mean density and cumulative GDD from April 1 to counting day when 2004 data were excluded. Rainfall ranged from $7 \mathrm{~cm}$ in 1998 to $24 \mathrm{~cm}$ in 2004 . Grass density and rainfall total before counting were not related.

The average grass density ranged from 12 (2004) to 131 (2003) plants $\mathrm{m}^{-2}$ (Table 3). Mean standard deviations ranged from 38 to 220 and indicated high variability among grid cell averages. Median annual grass densities ranged from 

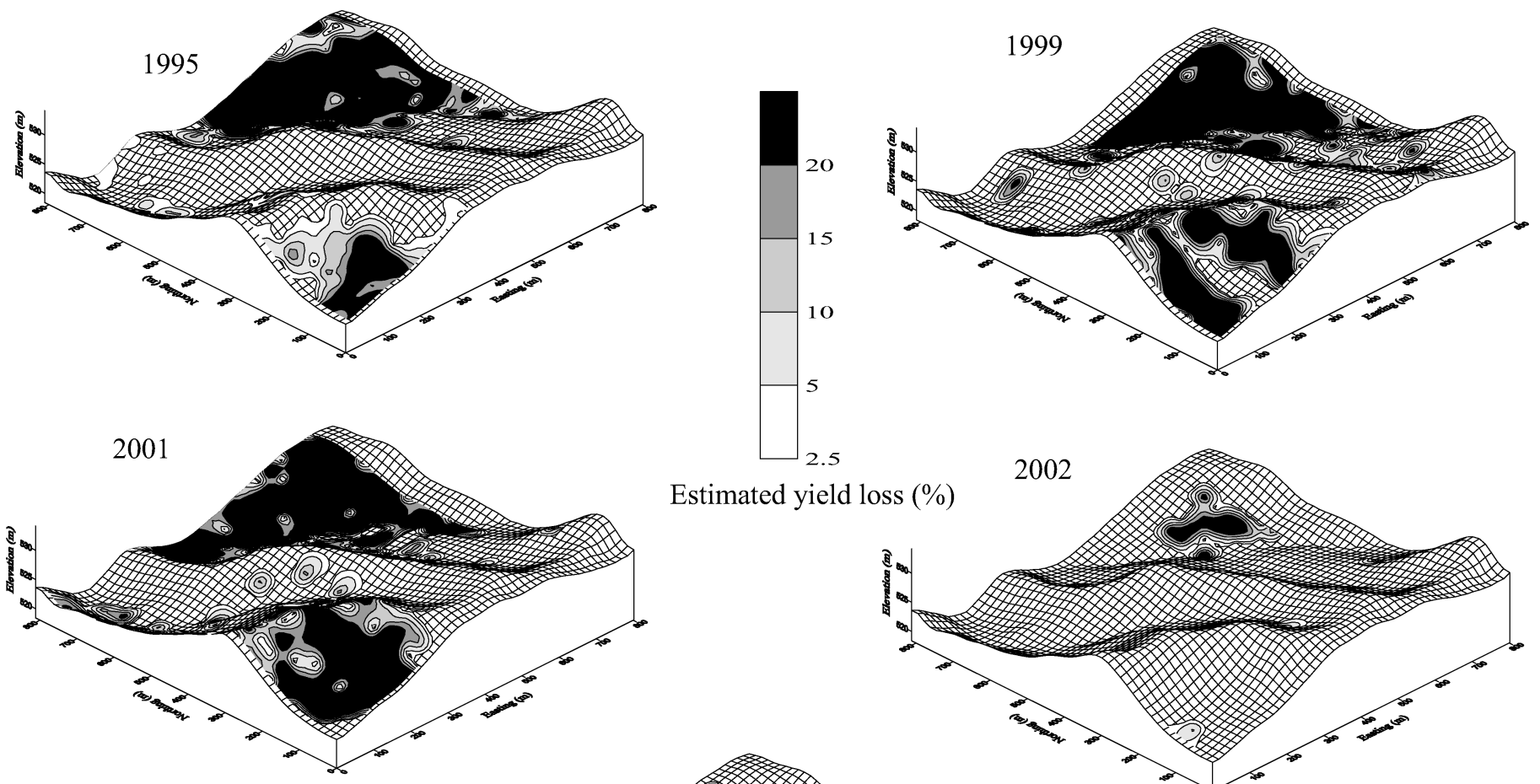

Estimated yield loss $(\%)$
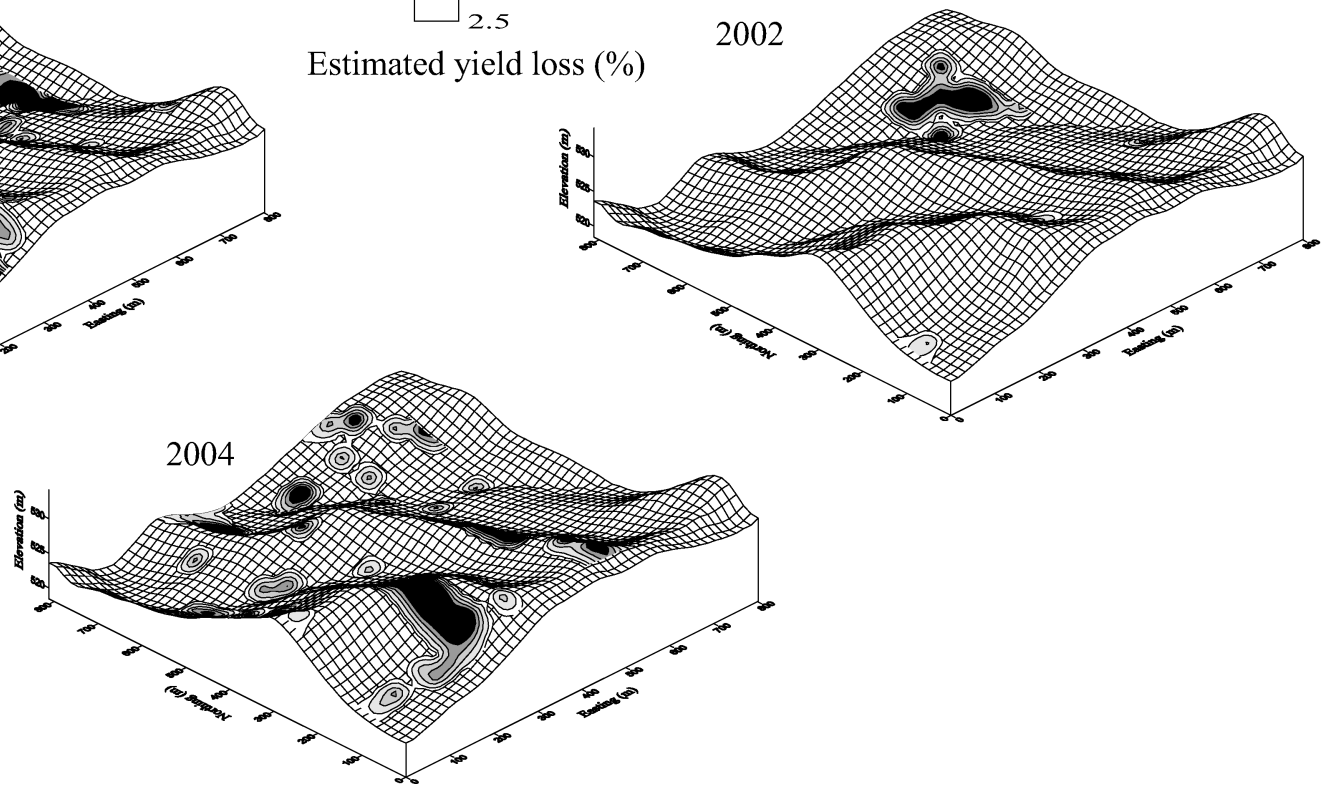

FigURE 3. Estimated corn yield losses (YL) on the basis of kriging common ragweed density per grid cell, an incremental YL value $(I)$ of $6 \%$ (Weaver 2001), and a maximum YL value $(A)$ of $50 \%$.

0 to 40 plants $\mathrm{m}^{-2}$. Using the Wilcoxon sign rank test (Conover 1980) by pairing consecutive corn/soybean years (2004 not included), the median grass density was greater $(\mathrm{P}=0.05)$ in soybean than in corn. Skewness values, a measure of the normality the data, were always greater than 0 (Table 3) and indicated that high densities dominated the data set (Ott 1977). Kurtosis values, a measure of the "heaviness" of the tails, ranged from 0 to 75.9. A kurtosis value of 3 indicates a normal distribution (Ott 1977), whereas values greater than 3 indicate distributions with large tails.

Specific density range frequencies differed among years (Table 4), with 24\% (2003) to $72 \%$ (1995) of the grid cells having no grass weeds. The percentage of grid cells that had grass densities $>50$ plants $\mathrm{m}^{-2}$ ranged from about $5 \%$ (1995 and 2004) to 44\% (2003). These data also indicate a nonnormal grass density distribution. During the study, $6 \%$ of the cells never contained annual grasses (Table 5), whereas $30 \%$ of the grid cells had annual grass weeds in 6 or more years of the study. These data indicate that annual grass patches were generally both temporally and spatially stable.

Grass weed distribution was somewhat influenced by location and field elevation (Figures 1 and 2). The eastern and northern field edges had high grass densities each year and may have been influenced by grass pastures that border these areas. In addition, grass densities generally were high every year in the diagonal water catchment that runs from the middle of the eastern boundary to the middle of the northern boundary.

\section{Spatial and Temporal Stability of Common Ragweed}

Common ragweed mean densities, except for 1995, were 10 to 100 times lower than the annual grass densities, and ranged from $<1$ to 37 plants $\mathrm{m}^{-2}$ (Table 3 ). Mean standard deviations were high, whereas the median density of common ragweed was 0 plants $\mathrm{m}^{-2}$. Skewness and kurtosis values for common ragweed data set densities were generally greater than those of grasses and indicated nonnormal distributions.

High proportions (from 64 to 97\%) of grid cells contained no common ragweed (Table 4), with infestations more localized than those of grasses and generally related to landscape position. The most severe infestations occurred in toeslope or upper backslope positions of the northeast and southwest corners of the field (Figures 3 and 4) where wet conditions were common in the spring.

Common ragweed infestations had less temporal stability 


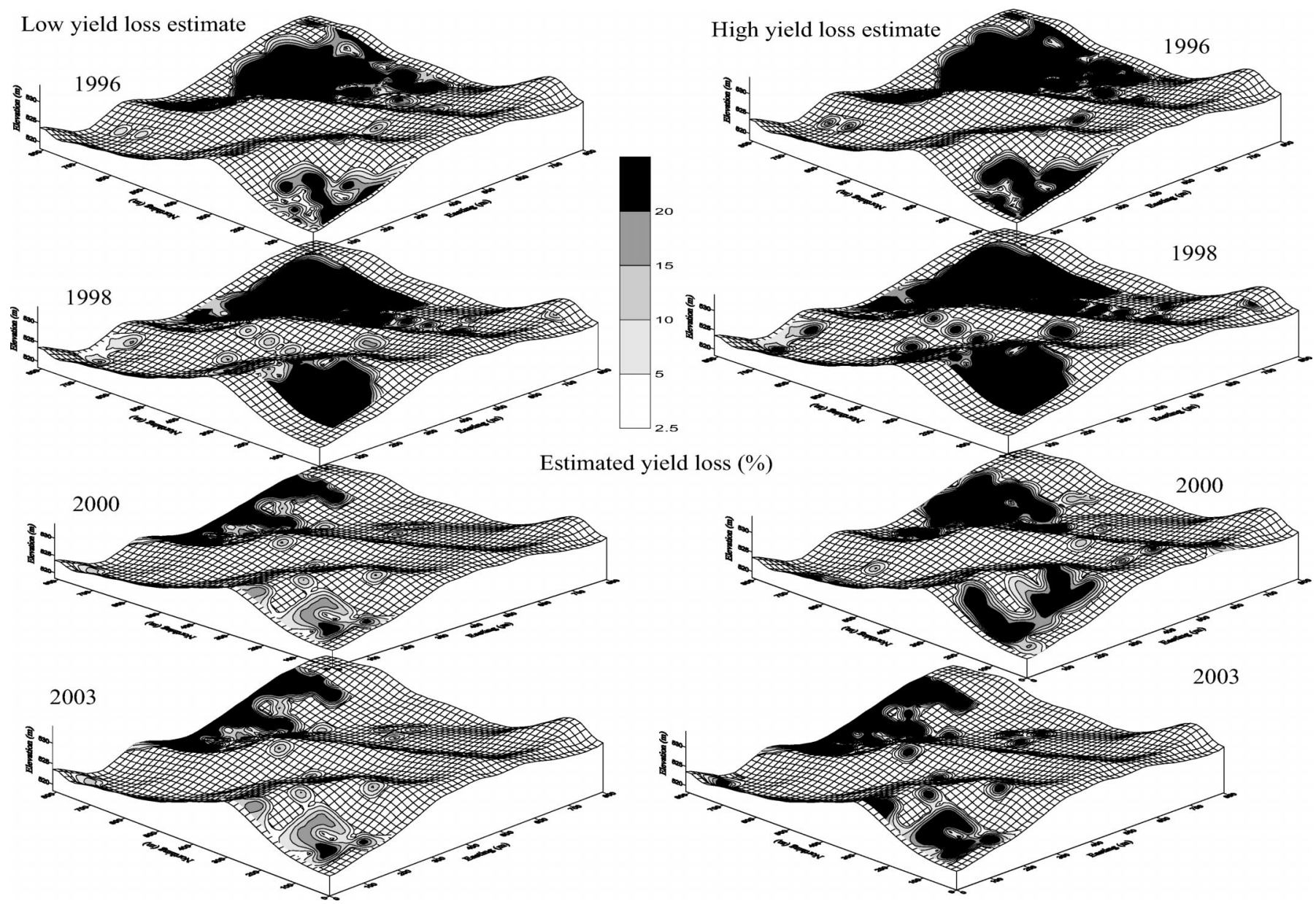

FIGURE 4. Estimated soybean yield losses (YL) on the basis of kriging common ragweed density per grid cell, incremental YL values $(I)$ of $5.1 \%$ (Weaver 2001) for the low YL estimate and 15.6\% (Cowbrough et al. 2003) for the high YL estimate, and a maximum YL value $(A)$ of $68 \%$.

than that of annual grasses. Common ragweed was not observed in $38 \%$ of the cells during the 9-yr study (Table 5), and $3 \%$ of the grid cells had common ragweed in 6 or more years. The low stability of this weed was most likely due to a successful control program.

\section{Treatment Recommendations on the Basis of Mean and Median Density}

Weed species had greater influence on estimating YL than weed density, or changes in $I$ or $A$ values within a crop

TABLE 6. Estimated annual grass and common ragweed densities that would result in 5, 10, or $15 \%$ yield loss based on the hyperbolic model (Cousens 1985) when the incremental yield loss value $(I)$ and maximum yield loss value $(A)$ were varied. The $I$ values chosen were the lowest and highest values and the $A$ values chosen include the lowest, average, and highest values reported in Table 2 by crop and weed combinations.

\begin{tabular}{|c|c|c|c|c|c|c|c|c|c|c|}
\hline \multirow[b]{2}{*}{ Crop } & \multicolumn{2}{|c|}{ Grassy weeds } & \multicolumn{3}{|c|}{$\begin{array}{l}\text { Estimated density } \\
\text { to cause yield loss }\end{array}$} & \multicolumn{2}{|c|}{ Common ragweed } & \multicolumn{3}{|c|}{$\begin{array}{l}\text { Estimated density } \\
\text { to cause yield loss }\end{array}$} \\
\hline & $I$ value & $A$ value & $5 \%$ & $10 \%$ & $15 \%$ & $I$ value & $A$ value & $5 \%$ & $10 \%$ & $15 \%$ \\
\hline & & & 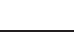 & lants $\mathrm{m}$ & & & & & nts $\mathrm{m}^{-}$ & \\
\hline \multirow[t]{6}{*}{ Corn } & 0.1 & 25 & 65 & 170 & 355 & 4.5 & 20 & 1.5 & 5 & 15 \\
\hline & & 43 & 60 & 130 & 230 & & 50 & 1 & 3 & 5 \\
\hline & & 75 & 50 & 115 & 185 & & 80 & 1 & 2.5 & 4 \\
\hline & 2.0 & 25 & 3 & 8 & 19 & 6.0 & 20 & 1 & 4 & 10 \\
\hline & & 43 & 3 & 6 & 12 & & 50 & 1 & 2 & 4 \\
\hline & & 75 & 3 & 6 & 10 & & 80 & 1 & 2 & 3 \\
\hline \multirow[t]{6}{*}{ Soybean } & 0.7 & 20 & 10 & 30 & 90 & 5.1 & 60 & 1 & 2 & 4 \\
\hline & & 66 & 8 & 17 & 28 & & 68 & 1 & 2 & 4 \\
\hline & & 100 & 8 & 16 & 26 & & 85 & 1 & 2 & 3 \\
\hline & 10 & 20 & 1 & 2 & 6 & 15.6 & 60 & $<1$ & $<1$ & 1 \\
\hline & & 66 & 1 & 2 & 2 & & 68 & $<1$ & $<1$ & 1 \\
\hline & & 100 & $<1$ & $<1$ & 2 & & 85 & $<1$ & $<1$ & 1 \\
\hline
\end{tabular}


TABLE 7. Estimated field yield loss (YL) based the hyperbolic yield loss equation and on the annual grass mean and median densities and the standard deviations of the means using low and high incremental yield loss values $(I)$ for annual grassy weeds in a Moody County, SD, field from 1995 to 2004 . The $I$ values used for corn were 0.1 and $2 \%$ yield loss per plant with a maximum YL $(A)$ of $43 \%$. The $I$ values used for soybean were 0.7 and $10 \%$ yield loss per plant with a maximum YL $(A)$ of $66 \%$.

\begin{tabular}{|c|c|c|c|c|c|c|c|c|}
\hline \multirow[b]{2}{*}{ Crop } & \multirow[b]{2}{*}{ Year } & \multirow[b]{2}{*}{$I$ value } & \multirow{2}{*}{$\begin{array}{l}\text { YL based } \\
\text { on mean }\end{array}$} & \multirow[b]{2}{*}{ Stdev } & \multirow{2}{*}{$\begin{array}{l}\text { YL based on } \\
\text { median }\end{array}$} & \multicolumn{3}{|c|}{ Frequency of cells with specified YL } \\
\hline & & & & & & $5 \%$ & $10 \%$ & $15 \%$ \\
\hline & & & & $-\%-$ & 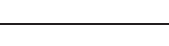 & & & \\
\hline \multirow[t]{10}{*}{ Corn } & 1995 & 0.1 & 1.0 & 2.4 & 0 & 0.06 & 0.03 & 0.02 \\
\hline & & 2.0 & 5.4 & 10.4 & 0 & 0.27 & 0.19 & 0.12 \\
\hline & 1999 & 0.1 & 2.1 & 4.1 & 0 & 0.12 & 0.06 & 0.02 \\
\hline & & 2.0 & 10.9 & 13.5 & 0 & 0.42 & 0.32 & 0.27 \\
\hline & 2001 & 0.1 & 3.9 & 5.2 & 1.4 & 0.27 & 0.13 & 0.06 \\
\hline & & 2.0 & 17.8 & 15.0 & 17.7 & 0.66 & 0.59 & 0.53 \\
\hline & 2002 & 0.1 & 3.2 & 5.2 & 0 & 0.24 & 0.12 & 0.06 \\
\hline & & 2.0 & 13.5 & 15.7 & 0 & 0.48 & 0.45 & 0.39 \\
\hline & 2004 & 0.1 & 1.0 & 2.5 & 0 & 0.05 & 0.01 & 0.01 \\
\hline & & 2.0 & 6.2 & 10.5 & 0 & 0.32 & 0.24 & 0.18 \\
\hline \multirow[t]{8}{*}{ Soybean } & 1996 & 0.7 & 12.8 & 18.6 & 25.0 & 0.41 & 0.35 & 0.35 \\
\hline & & 10 & 26.1 & 27.7 & 18.3 & 0.51 & 0.51 & 0.51 \\
\hline & 1998 & 0.7 & 19.4 & 20.7 & 9.6 & 0.59 & 0.48 & 0.44 \\
\hline & & 10 & 36.6 & 27.3 & 45.8 & 0.68 & 0.68 & 0.68 \\
\hline & 2000 & 0.7 & 16.9 & 18.3 & 9.6 & 0.59 & 0.48 & 0.41 \\
\hline & & 10 & 35.4 & 27.2 & 45.8 & 0.65 & 0.65 & 0.65 \\
\hline & 2003 & 0.7 & 22.7 & 20.4 & 20.0 & 0.67 & 0.59 & 0.43 \\
\hline & & 10 & 42.6 & 25.4 & 56.7 & 0.77 & 0.77 & 0.77 \\
\hline
\end{tabular}

(Table 6). The exception was grass weeds in corn that had a range of $I$ values from 0.1 to $2 \%$ and resulted in grass densities ranging from 10 to 355 plants $\mathrm{m}^{-2}$ to result in a $15 \%$ YL. The common ragweed plant density to cause a $10 \% \mathrm{YL}$ in both corn and soybean was often 2 or fewer plants $\mathrm{m}^{-2}$ because of greater competition than grass weeds and was reflected in higher $I$ and $A$ values.

On the basis of the mean grass density (Table 3), a low $I$ value $\left(0.1 \%\right.$ per grass plant $\left.\mathrm{m}^{-2}\right)$, and an $A$ value of $43 \%$ for corn, estimated YL was similar across years and averaged $2 \%$ (Table 7). The estimated YL was below even the 5\% YL trigger, so no treatment would have been recommended. However, the frequency of cells with $>10 \% \mathrm{YL}$ ranged from 1 (2004) to $13 \%$ (2001) (Table 7), indicating that there were areas with large estimated yield losses.

On the basis of the mean grass density and a 2\% I value, corn YL was similar across years, due to high standard deviations of the mean, and averaged $11 \%$ (Table 7 ). If the YL trigger for treatment recommendation was $10 \%$ the entire field would have been recommended for treatment. However, if the entire field was treated, 34 (2001) to 68\% (2004) of the field did not have densities high enough to cause a 5\% YL. On the basis of the field median density, estimated corn YL was only greater than 0 in 2001, with a YL of $1.4 \%$ when the low $I$ value was used, and about $18 \%$ when the high $I$ value was used. Changing the $A$ value from $43 \%$ to either 25 or $75 \%$ produced similar YL results (data not shown).

Fieldwide grass control in soybean would have been recommended each year on the basis of mean or median density estimates, high or low $I$ values, and $A$ value of $66 \%$ (Table 7). Using the $I$ value of $0.7 \%$, the $A$ value of $20 \%$, and the mean grass density would have resulted in a notreatment recommendation in 1996 and 2000 if the YL threshold was $10 \%$ and not $5 \%$.

On the basis of common ragweed mean densities (Table $3)$, treatment would have been recommended in every year except, perhaps, 2002 (corn) and 2003 (soybean), because of the high $I$ values per plant (Table 7 ). On the basis of the field median of 0 plants $\mathrm{m}^{-2}$, common ragweed treatment would not have been recommended in any year of the study.

\section{Treatment Recommendations on the Basis of Grid Cell Density and Kriging}

Weed densities were not evenly distributed across this field (Table 4) and estimating YL or basing treatment recommendations on the mean and median densities may be erroneous. Kriging of point estimates of yield losses across a field allows for site-specific recommendations and may increase the efficiency of management decisions.

Corn YL estimates due to grass and assuming a 100\% accuracy of the kriged map resulted in some areas where grass treatment was not needed because YL did not exceed 5 or $10 \%$ with either high (Figure 1) or low (data not shown) $I$ values. In most cases, using the 5\% YL trigger for treatment instead of $10 \%$ resulted in an increased treatment area rather than demarcations of new treatment areas. Sitespecific recommendations for grass treatment in corn would have resulted in a no-treatment recommendation for about 15\% (2001 high YL estimate, Figure 1) to 70\% (2004 low YL estimate) of the field.

Grass treatment recommendations in soybean years resulted in almost uniform broadcast applications in 2000 and 2003 when the high $I$ value was used (Figure 2). The lower grass $I$ value in soybean resulted in about a $15 \%$ decrease of the treatment area in 1996 and 1998.

Recommended common ragweed treatment areas were notably different from those of grass (Figures 3 and 4). These results were attributed to higher $I$ values but less overall presence of common ragweed than grass (Table 3). In corn, the treatment maps were similar whether based on the $I$ value of 4 or $6.5 \%$ YL per plant $\mathrm{m}^{-2}$, with the high $\mathrm{YL}$ map shown in Figure 3. Although the median density of 
common ragweed was 0 each year, there were still large areas where treatment would have been recommended in both corn and soybean on the basis of any $I$ value or level of acceptable maximum YL (Figures 3 and 4).

Annual grasses were found throughout this field and 30\% of the same grid cells had an infestation for 6 or more years and indicated a relatively stable spatial distribution over time (Table 5). Annual grass densities, on the other hand, were highly variable (Table 4). Common ragweed generally was found in only the lowest wettest positions in this field (Figures 1 and 3). Temporal stability was low with only 3\% of the sampled grid cells having a common ragweed infestation in 6 of the 9 sampling years (Table 5). Therefore, the sampling strategy for determining the spatial and temporal distributions of these two weeds would vary. Annual grasses may need to be surveyed once every few years across the entire field, whereas common ragweed may require a higher sampling frequency but only in site-specific areas.

Kriged maps of densities or YL estimates by species were an important tool to visualize treatment areas in this field. There were large areas of the field during corn years that did not require treatment for either weed type, whereas soybean generally had larger recommended treatment areas due to greater YL per weed.

There are limitations to maps that estimate weed density and YL because interpolation methods to estimate these values in unsampled areas may be inexact and unrealistic (Colbach et al. 2000a; Dille et al. 2002; Rew and Cousens 2001). For example, Dille et al. (2002) compared four different interpolation methods (point kriging, inverse distance weighting, minimum surface curvature, and multiquadratic radial basis function) and Colbach et al. (2000a) used different selection methods (random, systematic, and predicted map methods) to estimate weed density in unsampled areas. Each method was reported to be imprecise in predicting the density of unsampled areas, with most interpolation methods overestimating densities in low-density areas and underestimating densities in high-density areas. However, absolute accuracy of a weed density map to determine site-specific management strategies may not be needed (Dille et al. 2002). The overestimation of weeds in low-density areas would ensure that fewer weedy areas are overlooked when using the interpolated map as an application guide. Indeed, a promising direction for further research might be determination of how inaccurate a weed map can be without compromising valuable site-specific management recommendations.

\section{Sources of Materials}

1 SURFER 8: Surface Mapping System, Golden Software Inc., 809 14th Street, Golden, CO 80401.

\section{Acknowledgments}

This research was partially funded by USDA Grants 94-342141136, 99-36200-8702, and 2002-35108-11605; North Central IPM; EPS 0091948; South Dakota Soybean Research and Promotion Board; and South Dakota Corn Utilization Council. The authors thank Dave Dietrich for the use of the field and countless graduate and undergraduate students who experienced this field in an up-close and personal manner. South Dakota Exper. Sta. Manuscript No. 3508.

\section{Literature Cited}

Anderson, R. L. 2000. Cultural systems to aid weed management in semiarid corn (Zea mays). Weed Technol. 14:630-634.

Banken, K. 2000. Influence of yellow foxtail (Setaria glauca (L.) Beauv.) on corn (Zea mays L.) growth and western corn rootworm (Diabrotica virgifera virgifera, LeConte) development. M.S. thesis. South Dakota State University, Brookings, SD. 128 p.

Bensch, C. N., M. J. Horak, and D. Peterson. 2003. Interference of redroot pigweed (Amaranthus retroflexus), Palmer amaranth (A. palmeri), and common waterhemp (A. rudis) in soybean. Weed Sci. 51:37-43.

Cardina, J., D. H. Sparrow, and E. L. McCoy. 1995. Analysis of spatial distribution of common lambsquarters (Chenopodium album) in notill soybean (Glycine max). Weed Sci. 44:258-268.

Castro-Tendero, A. J. and L. Garcia-Torres. 1995. SEMAGI-an expert system for weed control decision making in sunflowers. Crop Prot. 14:543-548.

Cathcart, R. J. and C. J. Swanton. 2003. Nitrogen management will influence threshold values of green foxtail (Setaria viridis) in corn. Weed Sci. 51:975-986.

Chancellor, R. J. 1985. Changes in the weed flora of an arable field cultivated for 20 years. J. Appl. Ecol. 22:491-501.

Chikoye, D. and C. J. Swanton. 1995. Evaluation of three empirical models depicting Ambrosia artemisiifolia competition in white bean. Weed Res. 35:421-428.

Clay, S. A., K. R. Banken, F. Forcella, M. M. Ellsbury, D. E. Clay, and A. E. Olness. 2006. Influence of yellow foxtail (Setaria pumila) on corn (Zea mays) growth and yield. Comm. Soil Sci. Plant Anal. In press.

Clay, S. A., G. J. Lems, D. E. Clay, F. Forcella, M. M. Ellsbury, and C. G. Carlson. 1999. Sampling weed spatial variability on a fieldwide scale. Weed Sci. 47:674-681.

Colbach, N., F. Dessaint, and F. Forcella. 2000a. Evaluating field-scale sampling methods for the estimation of mean plant densities of weeds. Weed Res. 40:411-430.

Colbach, N., F. Forcella, and G. A. Johnson. 2000b. Spatial and temporal stability of weed populations over five years. Weed Sci. 48:366-377.

Conley, S. P., D. E. Stoltenberg, C. M. Boerboom, and L. K. Binning. 2003. Predicting soybean YL in giant foxtail (Setaria faberi) and common lambsquarters (Chenopodium album) communities. Weed Sci. 51: 402-407.

Conover, W. J. 1980. Practical Nonparametric Statistics. 2nd ed. New York: John Wiley and Sons. 493 p.

Cousens, R. 1985. An empirical model relating crop yield to weed and crop density and a statistical comparison with other models. J. Agric. Sci. 105:513-521.

Cowbrough, M. J., R. B. Brown, and F. J. Tardif. 2003. Impact of common ragweed (Ambrosia artemisiifolia) aggregation on economic thresholds in soybean. Weed Sci. 51:947-954.

Dieleman, J. A. and D. A. Mortensen. 1999. Characterizing the spatial pattern of Abutilon theophrasti seedling patches. Weed Res. 39:455467.

Dille, J. A., M. Milner, J. J. Groeteke, D. A. Mortensen, and M. M. Williams, II. 2002. How good is your weed map? A comparison of spatial interpolators. Weed Sci. 51:44-55.

Evans, S. P., S. Z. Knezevic, J. L. Lindquist, C. A. Shapiro, and E. E. Blankenship. 2003. Nitrogen application influences the critical period for weed control in corn. Weed Sci. 51:408-417.

Forcella, F., M. E. Westgate, and D. D. Warnes. 1992. Effect of row width on herbicide and cultivation requirements in row crop. Am. J. Altern. Agric. 7:161-167.

Gaston, L. A., M. A. Locke, R. M. Zablotowicz, and K. N. Reddy. 2001. Spatial variability of soil properties and weed populations in the Mississippi Delta. Soil Sci. Soc. Amer. J. 65:449-459.

Gerhards, R., D. Y. Wyse-Pester, and G. A. Johnson. 1997. Characterizing spatial stability of weed populations using interpolated maps. Weed Sci. 45:108-119.

Isaaks, E. H. and R. M. Srivastava. 1989. An Introduction to Applied Geostatistics. New York: Oxford University Press. Pp. 249-266, 278322.

Johnson, G. A., D. A. Mortensen, and C. A. Gotway. 1996. Spatial and temporal analysis of seedling populations using geostatistics. Weed Sci. 44:704-710.

Johnson, G. A., D. Mortensen, L. J. Young, and A. Martin. 1995. The stability of weed seedling population models and parameters in eastern Nebraska corn (Zea mays) and soybean (Glycine max) fields. Weed Sci. 43:604-611. 
Jurado-Exposito, M., F. Lopez-Grandos, L. Garcia-Torres, A. Garia-Ferrer, M. Sanchez de la Orden, and S. Atenciano. 2003. Multispecies weed spatial variability and site-specific management maps in cultivated sunflower. Weed Sci. 51:319-328.

Lindquist, J. L., D. A. Mortensen, P. Westra, et al. 1999. Stability of corn (Zea mays)-foxtail (Setaria spp.) interference relationships. Weed Sci. 47:195-200.

Marshall, E.J.P. 1988. Field-scale estimates of grass weed populations in arable land. Weed Res. 28:191-198.

Moechnig, M. J., C. M. Boerboom, D. E. Stoltenberg, and L. K. Binning. 2003. Growth interactions in communities of common lambsquarters (Chenopodium album), giant foxtail (Setaria faberi), and corn. Weed Sci. 51:363-370.

Ontario Ministry Agriculture and Food (OMAF) Staff. 2003. Publication 811, Agronomy Guide for Field Crops. www.gov.on.ca/OMAFRA/ english/crops/pub811.
Ott, L. 1977. An Introduction to Statistical Methods and Data Analysis. North Scituate, MA: Wadsworth Publishing. 703 p.

Rew, L. J. and R. D. Cousens. 2001. Spatial distribution of weeds in arable crops: are current sampling and analytical methods appropriate? Weed Res. 41:1-18.

Tollenaar, M., S. P. Nissanka, A. Aguilera, S. F. Weise, and C. J. Swanton. 1994. Effect of weed interference and soil nitrogen on four maize hybrids. Agron. J. 86:596-601.

Weaver, S. E. 2001. Impact of lamb's-quarters, common ragweed and green foxtail on yield of corn and soybean in Ontario. Can. J. Plant Sci. 81: $821-828$.

Wilson, B. J. and P. Brain. 1991. Long-term stability of distribution of Alopecurus myosuroides Huds. within cereal fields. Weed Res. 31:367373.

Received July 7, 2005, and approved December 22, 2005. 